\title{
Editorial
}

\section{CREATING SUBJECTIVITIES}

\section{Lisa Blackman, John Cromby, Derek Hook, Dimitris Papadopoulos and Valerie Walkerdine}

Subjectivity (2008) 22, 1-27. doi:10.1057/sub.2008.8

$\mathrm{W}$

elcome to the first launch issue of Subjectivity, previously the International Journal of Critical Psychology. Subjectivity is an international, transdisciplinary journal that will explore the social, cultural, historical and material processes, dynamics and structures of human experience. As topic, problem and resource, notions of subjectivity are relevant to many disciplines, including cultural studies, sociology, social theory, science and technology studies, geography, anthropology, gender and feminist studies and psychology. The journal will bring together scholars from across the social sciences and the humanities in a collaborative project to identify the processes by which subjectivities are produced, explore subjectivity as a locus of social change, and examine how emerging subjectivities remake our social worlds. Our aim, then, is a re-prioritization of subjectivity as a primary category of social, cultural, psychological, historical and political analysis.

Subjectivity will be collectively edited by Lisa Blackman, John Cromby, Derek Hook, Dimitris Papadopoulous and Valerie Walkerdine. The group brings together expertise in various relevant fields including psychology, sociology, social theory, psychoanalysis, postcolonial theory, feminism and gender studies, and media and cultural studies. We hope that our combined expertise and experience will enable us, in ongoing consultation with our editorial board, contributors and readers, to forge a path that captures ongoing debates and activities. We aim to foster a discourse on subjectivity that goes beyond the established dichotomies that exist between various humanities and social science disciplines, and to problematize the distinctions that are often made between the social, historical, cultural, psychological and political as if they can be examined as separate categories and entities.

Subjectivity has been an important concept for academic research, and for intervening in social and political life, since the 1960s. Since then, notions of 
subjectivity have had a catalytic impact in changing the terms of debate across many areas of the social sciences. The history of this concept provides many of the conditions of possibility for the project in which we are now engaged; accordingly, we will now sketch a necessarily partial, contingent and provisional account of its conditions of emergence and use in recent decades.

In the aftermath of May 1968, the student revolt and the failure of the workers to join the students, there was a re-examination of the role of ideology within European Marxism. This can also be put alongside the significance of already existing concerns on the Left about the role of the Soviet Union in Eastern Europe and the rise of Eurocommunism. In Britain, this was facilitated by what we can understand as the rise of the New Left, and the start of the journal New Left Review, edited by Stuart Hall. It is in this moment that we can see the burgeoning of work that was to become fundamental to an interest in subjectivity and its central importance for reformulating radical politics.

\section{Ideology, hegemony and the theory of the subject}

The failure of the workers in France to join the students and call for a general strike led to a general concern on the French Left with the reasons for this. It was to theories of ideology that people turned to explain the situation in which apparently the workers did not do what would seem to support their interests. We might think of the work of Althusser as defining, in the sense that its take-up for the first time placed the study of human subjectivity centre stage in a Marxist project of radical political transformation. A frequently used approach from what became known as economistic Marxism was exemplified by Braverman (1974) in Labour and Monopoly Capital, who argued that, for example, schools provided workers for the economy along the lines of a sausage factory - you put in children and get out workers. This means that what happens in the school is not worth engaging with - it is the output of workers that matters. Althusser's famous ISA's essay (Althusser, 1971) completely stood that idea on its head. He argued that it was effectively what happened within the institution that was crucial and that in fact, the economy only mattered "in the last instance", an instance that, in fact, never comes. He argued that, if we continue the school analogy, ideological state apparatuses (Althusser cited the army and the church as well as the school) create subjects by producing identities. They do this by a process of interpellation or hailing. That is, they hail a school student as, for example, an A or a $\mathrm{C}$, having learning difficulties, etc. It is this process of interpellation that, Althusser argued, creates subjects and it is this that is the ideological work, which is, in the end, more important than the last instance of the economy. Thus economic determinism was seen as oversimplistic and failing to take account of ideological processes in the making of subjects. In addition to this, Althusser turned to Lacan to support his theory of interpellation by referring to Lacan's account of the mirror stage. This had considerable importance in the re-awakening of interest in psychoanalysis, with 
many coming to psychoanalysis for the first time not through Freud but through Lacan (e.g. Lacan, 2002) - not the easiest or most obvious of sources!

What is significant here is that this led not only to the central importance of ideology but to what became known as the need for a Theory of the Subject. Note here the singular theory and singular subject, who could be understood through structural Marxism on the one hand and an account of the psychoanalytic formation of the subject on the other. The use of Lacan also paved the way for the centrality of a non-biologistic subject - one rather created through signs - and for the central importance of psychoanalysis for the study of ideological processes. For example, the journal Screen for a period devoted itself to a psychoanalytic reading of cinema through an account of spectatorship. In this analysis, the subject was created as a position or an interpellation and so, in order to get away from a pre-existing subject who determined what was understood, it was the semiotic, psychic and ideological processes themselves that created the subject - discursively and psychoanalytically.

This account of the discursive creation of ideological positions as the way of studying subjectivity and ideology was considered by some to be overly passive. In some ways this is a misreading of the activity of the unconscious but it is definitely the case that, for example, in cinema studies, it was as though a subject was produced simply and only through the relations of desire in the film. That the film was watched by people with pre-existing processes of subjection was not really considered at this point, although clearly it was made more complex later.

But the reason for stating this is that we want to contrast it with the use of another account of ideology, that of Antonio Gramsci (1971). Gramsci's work was taken up by Stuart Hall and was central to the founding of cultural studies. Gramsci's concept of hegemony became crucial for the development of the Centre for Contemporary Cultural Studies in the 1970s. In particular, some cultural theorists argued that the Althusserian and Lacanian account was too static and did not allow for an active subject. For this reason they concentrated on the cultural processes of active resistance to dominant ideologies. Perhaps best known are Resistance through Rituals (Hall and Jefferson, 1989), in which Hall and Jefferson argued that young men used youth culture as a way of resisting the dominant culture and codes of masculinity, thus creating the possibility for radical action, and hence this was understood as less determinist than Althusser's position. Or Dick Hebdige's Subculture: the meaning of style (1979), which used semiotics to analyse resistant style, mostly the punk use of the safety pin. By subverting the meaning of the safety pin, the punks, he argued, were making a radical and transformative act.

What links these two approaches is the turn to language, signs and discourse as the site through which subjects are formed. This relates to a move away from biology on the one hand and the economy on the other. It is this work that profoundly shaped radical work across the humanities and social sciences for 
the next 30 years, which founded a new field, Cultural Studies, and which, in many ways, helped sow the seeds of the intellectual death knell of Marxism. It is this period and these debates that, more than anything else, in Europe and North America at least, produced a climate in which the word "subjectivity" became central.

\section{Experience and feminism}

Although the CCS work draws upon Gramsci, the emergence of Cutural Studies from the disciplines of English and History via the work of Raymond Williams (1977), Richard Hoggart (1971) and Edward Thompson (1963) is worth mentioning. Hoggart and Williams were both working-class grammar school boys and Williams went to Cambridge. All three had been active in workingclass education. Thompson wrote the seminal volume, The Making of the English Working Class (1963), which had argued that the experience of certain craftspeople was absolutely central to the formation of a working class. In other words, he argued that it was experience which allowed them to come together as a group who could see their shared interests. In this sense, his work attempts to understand the experience of exploitation rather than simply looking at the economy (cf. Braverman) or indeed ideology as obfuscating. This focus on experience is further developed by Hoggart (1971) in his studies of workingclass people and culture and similarly echoed by Williams in his account of working-class experience and culture. Williams in fact proposes a notion of "structures of feeling" (Williams, 1977), which, although underdeveloped and notoriously difficult to define, could in some ways be said to form an important antecedent to the current interest in affect.

In addition to this, the focus on experience and culture makes the terrain of understanding of class through cultural experience centrally important and thus provides an, in many ways, opposing view to that presented by the Althusserian tradition. This is where what is foregrounded is the site of popular culture, which is taken to provide the signs through which unconscious identifications are made. What is significant in this is that it equally presents the cultural as a site for the production of subjectivity, but in stressing experience, it again echoes the current resumption of interest in experience and also the active participation of those making culture (Stephenson and Papadopoulos, 2006). Indeed, this distinction spawned a serious split and debate on the Left in the 1980s. Thompson opposed Althusser and this led him to write Writing by Candlelight (Thompson, 1980). The Left split on the issue of whether signs produced experience or whether experience was primary, and this split can only be seen to be healed by the emergence of new work 30 years later, which cuts across these distinctions. We will come to this later. Moreover, this split tended to produce an idea of active resistant subjects of cultural studies $v s$ passive dupes of ISAs. This is a very crude misreading of the complexities of both positions but 
it tended to be operationalized in cultural and television studies approaches $v s$ work on film, for example.

During this time - and we are here moving through the 1970s - there was an incredible burgeoning of radical intellectual work in Britain, mostly seen through new journals, such as Screen, Radical Philosophy, Radical Science Journal, m/f, Feminist Review, Ideology and Consciousness, Papers in Contemporary Cultural Studies, to name but a few. Most, in the beginning, were self-published; something that would be impossible and unthinkable now at least in paper.

At the same time, the impact of feminism has to be taken into account. Feminism's insistence that the "personal is political" also pointed the way to a different style of political engagement, particularly one that moved away from the idea of a vanguard party. Feminism's emphasis on consciousness-raising, and later unconsciousness-raising, stressed the central importance of the ideological in the production of women's oppression. In particular, for our purposes, Juliet Mitchell's text Psychoanalysis and Feminism (1974) challenged the idea that Freud was antithetical to feminism. A split developed between some forms of feminist psychoanalysis and psychotherapy and others, with the development of considerable support for Lacan and French feminist analysts (Kristeva, Irigaray, Cixous for example) and away from the British school, especially Klein, Bowlby, Winnicott and the importance of Juliet Mitchell and Jacqueline Rose's volume of Lacanian writings on sexuality (Mitchell and Rose, 1983). It is worth noting that this particular line stressed desire and semiotics (consider e.g. the work of Teresa de Lauretis, 1984), and the object relations approaches stressing affect and the body were scarcely considered (except perhaps in Suzie Orbach's work Fat Is a Feminist Issue; Orbach, 1978). This work certainly took the body as central, but this was not really thought about in relation to the stress on subjectivity as formed through desire and signs, ideologically. Yes, the emphasis was there on how bodies were formed ideologically, but it contrasts markedly with current interests in the workings of the body, neurology, affect, imagination, and desire in material and cultural processes.

\section{Althusser to Foucault: from structuralism to poststructuralism}

It is in this moment that another important shift in our understanding of subjectivity took place: In this section we want to think about the importance of the move from ideology to power/knowledge and from a theory of the subject to an understanding of subjectification/subjection. We want to begin by citing the founding editorial of a journal, Ideology and Consciousness, from 1976. This statement about psychology, ideology and the human subject sums up the post-Althusserian position quite nicely:

This position conceives of the social formation as a complex, over-determined and contradictory nexus of discursive practices, in which the human subject 
is constituted and lives in a relation of absolute interiority. No region or level of the social formation is contemplated which stands outside the discursive practices in which the material activities of concrete subjects consist; the social formation is equivalent to the non-unified totality of these practices. The human subject is not seen as occupying a given "place" within a "social structure", but as constituted in the intersections of a determinate set of discursive practices which take their particularity from the totality of practices in which they are articulated. The concept of discursive practice thus theorises the internal relation between the constitution and existence of human subjects in the totality and the alwaysongoing processes of production and reproduction of that totality. (Adlam et al., 1976, p. 46)

In addition, the journal title, linking ideology and consciousness, makes that Althusserian/Lacanian axis clear. In its later issues, the journal changed its name to $I$ and $C$. This was much discussed in the small circles around the journal as signalling a retreat from Marxism. What it could also be understood as is a move towards poststructuralism, particularly the work of Foucault, and away from the structuralism of Althusser. This shift was seen to be one that took us towards an acknowledgement of plurality and the historical specificity of structures. This move signalled a sense that Foucault's work on power/ knowledge understood subject positions as formed within the apparatuses of power/knowledge, the discursive practices and technologies of the social through which subjectification occurred. That this was historically specific and plural was crucial. We moved away from a singular theory and a singular pathway understood through psychoanalysis. This also implied moving away from ideology. This is because Foucault understood the human and social sciences, for example, as creating knowledge that itself was a "fiction functioning in truth" or a "regime of truth". He therefore followed Althusser but went beyond him, in claiming not that science was ideological but that all knowledge was itself fictional and productive of subjects. This placed a great deal of emphasis on the historical emergence or genealogy of the present "truths", and on the multiple sites through which these historically contingent truths are productive of positions for subjects to be formed. It is important to note that Foucault also rejected Althusser's singular causal chain leading back to the economy, in favour of a more complex place for the economy as one of the multiple conditions of possibility. This was widely understood as the final rejection of Marxism. Thus, we can begin to see a distinction between subjects as produced in power/knowledge and subjectivity, which we could call the experience of being subjected. It is important to separate one from the other. Subjectivity, in this account, is the experience of the lived multiplicity of positionings. It is historically contingent and is produced through the plays of power/knowledge and is sometimes held together by desire. 
This account was taken up with great vigour in certain quarters and while $I$ and $C$ was one of the first places to publish Foucauldian work in English, the use of this approach is now ubiquitous. It is worth noting that this relied upon Foucault's work before the publication of the second and third volumes of the History of Sexuality. We will come to this in due course. First, it is important to note the development of this work with respect to subjectivity via the jointly authored book Changing the Subject (Henriques et al., 1984). This book attempted to link together a Foucauldian approach to subjectification with an attempt to use psychoanalysis to understand how positions were held together for any one subject. The slippage around the word "subject" is worth noting here. In Foucault the subject is discursive in that it is a textual position. This is not co-terminous with the person. The issue about how this maps onto practices and experiences of people is a matter that Foucault does not consider in this early work. Thus the authors of Changing the Subject attempted to work on subjectivity as "more than the sum total of positions in discourse since birth", and so to use psychoanalysis in conjunction with Foucault to understand the complexities of the experience of being a subject, subjectivity.

Foucault's later work transformed the ways in which some, notably those associated with governmentality theory, approached Foucault's account of subjection. Here, experience was experience of self-regulation and it is in this work that the body came to have more salience. Those using this framework were quite against any in-depth reading of an idea of unconscious processes because it implied a transhistorical subject, which took us back to Althusser. It is in this interplay between the subject and subjectivity that the current horizon of interest in subjectivities is born, and which has produced some of the productive tensions that are now being played out in new and novel ways.

\section{Why the prioritization of subjectivity now?}

\section{Towards an ontology of the subject}

There is an important philosophical correlate to the attempt in Changing the Subject to grapple with subjectivity as more than a subsidiary effect, as more than the sum total of combined discursive positions. The imperative for such a philosophical attempt at understanding subjectivity as maintaining its own distinctive, "non-derivative" ontology is to be found in a moment of crisis. This is a moment of crisis that ushers in a very different intellectual tradition from the Althusserian, Foucauldian and Structuralist motifs discussed above; it is certainly one in which the commonplaces of poststructuralist adherence to discourse/signification are called into question. Feltham and Clemens (2003), in an introduction to Badiou's Infinite Thought, call attention to just such a moment: his L'Etre et l'événement Badiou (1988) focuses on a crucial comment 
made in Lacan's (1977) Seminar XI (The Four Fundamental Concepts of Psychoanalysis). Perhaps surprisingly, the comment is not made by Lacan but by Jacques-Alain Miller, who asks pointedly of Lacan: "What is your ontology?". This is a question that we may extrapolate to: "what is your distinctive ontology of the subject?". For Badiou, the urgency of this situation concerns the fact that much of the philosophy of his - and our own - generation seems unable to reconcile a doctrine of the subject with ontology. What we are dealing with here, to drive forward this argument, is an apparent inability to develop a complex and distinctive ontology that takes the subject as its central and foremost focus rather than explaining it in terms of a variety of other ontological principles. Now to be clear, as Feltham and Clemens (2003) emphasize, Badiou accepts that the subject of the contemporary world cannot be theorized as the "self-identical substance that underlies change, nor as the product of reflection, nor as the correlate of an object" (p. 3), so he is by no means advocating a return to previous commonplaces of philosophy. What is being called for here - at least in part - is a new order of theorization, a new conceptualization of the subject.

It is worthwhile to briefly explore one variation of Badiou's critique. One should bear in mind that there are a variety of conceptual frames within which we might demonstrate something of the particular problem at hand; Badiou's target is far wider than Lacanian psychoanalysis: analytical philosophy, structuralism and poststructuralism all number among the approaches he takes to task. The dilemma at hand is perhaps most dramatically evidenced in Foucault, who makes for a good reference point given the ongoing popularity of his work. In reference to Foucault's later genealogical work, we might state the problem as follows: there has been a merger of the subject with a general ontology of discourse, power and historical events such that there is no longer anything self-defining or distinctive about this subject itself. The subject here is always the subsidiary component of a different category of philosophical speculation, the by-product that seems wholly determined by just such forces. Or, to adopt for the moment a broadly constructionist ethos: what else is the subject here other than a produced form, the outcome of a complex constellation of textual, material, institutional, historical factors?

In too many instances then we approach the subject as an epi-phenomenon, as an outcome of operations of power-knowledge; as subsidiary element relative to structure; as the result of various instances and variations of the signifier, and so on. To return then to a Foucauldian theorization of the subject: if we are not to rely on any distinctive ontology or theory of the subject that exceeds the explanations of power/discourse/history, then how might we account for the different level of effects that power has in relation to subjects who are differentially produced? An initial Foucauldian response to the problem posed above might be to argue that if individuals are indeed differentiated, then this is 
already an effect of normalizing power that precisely compares, contrasts and hierarchizes individuals; there are indeed individual differences, but these are precisely recognized within a horizon of power. There is perhaps some validity to this claim, but there remains nevertheless something unsatisfactory in such a response, certainly so inasmuch as it brings us very close to a "blank slate" theory of the subject (Hook, 2007). This of course was one of the preoccupations that led to the seminal work published in Changing the Subject. Might we not accept the full significance of Foucault's important arguments concerning the differentiation and production of individuals and not still suggest that the "subjectivity" of such individuals is not wholly accounted for by power, discourse and historical circumstances? To what extent should we be examining those "somatic singularities" (Foucault, 2006) that allow the operation of disciplinary power to take hold? Or do we need a different analytics of power, as with the work of Deleuze (1990) and his concept of the "control society"? These are important points to consider and the extent to which some responses appear to take us back to a position in which there are forms of materiality out of which subjectivity is modulated and augmented demand to be debated. It is this which signals an interest and, for some social scientists and humanities scholars, a turn to neuroscience (Connolly, 2002; Massumi, 2002; Stafford, 2007). Whether this is a good thing and how this might be developed necessitate a detailed discussion and debate, which we welcome in the pages of this journal.

There is also another problem that is present here: the issue of agency. We know that for Foucault power/knowledge makes individuals, and furthermore, that power - in the context of the intricacies of its applications, failures and particularized negotiations - may be said to produce modes of resistance. The resulting problem, in terms of Badiou's philosophy, lies in accounting for the source of resistance:

If the subject - right down to its most intimate desires, actions and thoughts is constituted by power, then how can it be the source of independent resistance? For such a point of agency to exist, Foucault needs some space which has not been completely constituted by power, or a complex doctrine on the relationship between resistance and independence. (Feltham and Clemens, p. 4).

Foucauldian theorizations thus appear to foreclose the possibility of subjectivity as a viable resource of resistance, something that a new and distinctive ontology of the subject might make possible. We have then, in the domain of contemporary French philosophy - more particularly, Badiou's insistence on the need for a distinctive ontology of the subject - a remarkable echo, and indeed support, for the project proposed in forums such as Changing the Subject and $I$ and $C$ : namely that of the innovative intellectual attempts at analysing the multiple and diverse facets of subjectivity itself. 
Here we can pinpoint two priorities of Subjectivity. Firstly, to continue the work of an eclectic inventory of subjectivity that reads prior intellectual conceptualizations in the light of current political priorities. Secondly, to explore unorthodox combinations of different registers of analysis that are able to fathom the complexity of subjectivity via a series of tactical alignments between and across disciplines. We are thus emphatically not calling for a return to a naïve individualizing humanism, to de-socialized, a-historical categories of explanation, or to an essentialist inner mechanics of psychological functioning. However, notwithstanding this aversion to de-politicized modes of explanation, to the multiple problems associated with reductive psychological individualism, we remain nevertheless interested in an exploration of those ostensibly psychological frameworks and vernaculars - contingent as they may be - that may enable even a temporary hold on the unique density and complexity of subjectivity which is always more than a derivative formation. There is far more work to be done, for example, in linking the current recourse to affect, central to much contemporary sociological and cultural studies work, with models of psychical or neurological functioning that do not bring in psychological individualism through the back door. In this context it is worth spending some time outlining Nikolas Rose's analysis of the function and significance of the psychological sciences in neo-liberal regimes of governmentality, and his rejection of the individualism at the heart of such disciplines.

\section{The psychological complex}

Nikolas Rose's impressive body of work developed Foucault's claims that the psychological sciences were sciences of population management, what Rose (1985) termed the "psy complex". Rose (1998) drew on Foucault's later work in the three volumes of the History of Sexuality to explore the active participation of subjects in their own subjection in the form of technologies of subjectivity and self. This work has been hugely important and influential across the humanities, providing a framework for thinking about the achievement of subjectivity as a thoroughly technical, material and discursive process of assembling and acting upon oneself through a variety of practices of selfproduction. As Rose suggests, these practices are not simply epistemological (knowing oneself through a particular regime of personhood, for example), but are also corporeal (the shaping of bodies) and intellectual (what Rose (1998, p. 31) terms the "implantation of certain capacities of reading, writing, and calculating”). This work has appeared and forms the background to discussions of the relationship between discourse and the production of experience in studies of work and labour practices, media cultures, therapeutic and psychiatric cultures (Blackman, 2001; Orr, 2006), digital and biotechnological practices to name a few of the diverse sites.

Although the emphasis on practice and process moves discussions of subjectivity beyond a singular subject, Rose suggests that a history of such 
subjectifiying practices can be written without having any recourse to a "metapsychology" (p. 37). For Rose, we do not have or possess a subjectivity (even if it is discursively produced), and the possible "glue" that holds the subject together does not require the kind of psychoanalytic account that has been characteristic of works attempting to explain the relationship between subjects and subjectivity, without collapsing one onto the other (Walkerdine, 1990, 2007; Butler, 1993a; Clough, 2000; McRobbie, 2005). Some of the issues this raises are cogently made visible by considering some of the problems and possibilities with Rose's (1998) turn to Deleuzian concepts to theorize subjectivity, through the mobilization of the fold, for example. Such that the

human being, here, is not an entity with a history, but the target of a multiplicity of types of work, more like a latitude or a longitude at which different vectors of different speeds intersect. The "interiority" which so many feel compelled to diagnose is not that of a psychological system, but of a discontinuous surface, a kind of infolding of exteriority. (Rose, 1998, p. 37)

Although the move to Deleuzian concepts to reformulate the subject-as-process has been a popular way out of this dilemma, the extent to which such work resolves this paradox is one that we hope will be debated within Subjectivity. Indeed, in Paul Stenner's contribution to this launch issue we see what might have been omitted in Deleuzian thinking, and what could usefully be foregrounded in reformulations of subjectivity via the work of Alfred North Whitehead. As Stenner argues, scholars currently engaging with Whitehead's writings have had much to say about the psychology/physiology interface, but much less about the psychosocial or sociopsychic interface. In more processual accounts derived from such work, the subject is always in a process of becoming, extending any notion of singularity to a plane of vectors, speeds, multiplicities and movement. With this flattening of the subject, the arena of subjectivity is effectively evacuated, becoming a container for fixity, stasis and continuity (cf. Massumi, 2002). It would seem that subjectivity has to be "given up" in such a politics of emancipation and, as feminist scholars such as Claire Hemmings (2005) have argued, left as the focus of "bad theory" contrasted with those who are positioned as at the new "cutting edge". As Stenner argues, it is important to provide some clarity about subjectivity if one is not to recruit Whitehead into a set of concerns alien to his own. Similarly, Blackman $(2007,2008)$ has argued in relation to both the revitalization of William James and Gabriel Tarde within affect theory and Actor Network theory, that it is as important to explore what is being omitted and left out of their concerns if we are to open affect, relationality and subjectivity to new theoretical horizons.

Although we do not want to entrench such debates it is hoped that Subjectivity will provide a forum where the problems and possibilities of such moves can be 
opened up to interrogation. Although these debates are transdisciplinary, what is striking about the contributions to this first issue of the journal are the different genealogies that are at work. Debates across the humanities at this particular intellectual and historical moment are coalescing in relation to concepts such as affect and relationality. However, it would seem that we are often ill-informed of work going on at the margins of many disciplines, psychology, anthropology, sociology, science studies, philosophy, psychoanalysis, gender studies, feminism, geography and cultural studies, that might give rise to rather different characterizations of concepts of affect, relationality and subjectivity. This can be clearly seen in the dialogues that might be opened up about the psychosocial when we read Paul Stenner in relation to the contribution of Nigel Thrift, and Margaret Wetherell in relation to Lynne Layton.

What is also apparent from putting such work together, in what is an exciting and stimulating launch issue, is just how poorly psychological issues are dealt with both implicitly and often explicitly within discussions of subjectivity. One should not overlook the many promising innovations afforded in this respect by postcolonial theory, much of which, particularly in the work of Bhabha (2004), Fanon (1967), Moore-Gilbert (1997), Young (1990) and even in the recent work of Gilroy (2004), makes very explicit reference to psychoanalytic theorizing in order to formulate responses to various impasses posed by various states and conditions of postcolonial racism. As has been argued elsewhere (Hook, 2005), this body of work offers a variety of analytical frameworks that make enormously productive use of psychical/psychological concepts in theorizing presiding postcolonial formations of power. One might develop this point in a different way altogether: given that the psychological sciences are increasingly seen as knowledge practices providing a useful array of concepts for thinking body, brain and culture, such an analytics might produce some productive tensions for Subjectivity and its readers. For even as facets of psychological language are dispensed with in Rose and Foucault's genealogies, they remain implicitly present aspects necessary to make the account work. This importantly represents only one particular line of investigation for further explorations of the rich problematic of subjectivity; it by no means exhausts the conceptual avenues, or further - even if apparently contrary - directions that we have available to us, a variety of which will be discussed in what follows.

\section{Critical psychology}

Critical psychology has been a small but important movement in the last 20 years. Its promotion of anti-individualist, pro-social perspectives has challenged the precepts of cognitivism that currently lie at the core of the discipline of psychology, besides spawning vociferous sub-elements of critical social, critical clinical and critical health psychology (Ibanez and Iniguez, 1997; Murray, 2004; Smail, 2005). Important trends within critical psychology (Holzkamp's 
analyses, social constructionism, feminism, psychoanalysis, poststructuralism, Foucauldian analyses, activity theory) were initially somewhat disparate, at least among the English-language community, but began to coalesce during the late 1980 s to produce a relatively distinctive subdiscipline. Some elements of critical psychology were imported more-or-less wholesale from other disciplines, and while this sometimes led to a hollowing out of the psychological and its reduction to other analytics (the social, language, power), it has also produced some useful and distinctive work. In particular, versions of the subject have been reworked to emphasize openness, multiplicity and social influence (e.g. Bayer and Shotter, 1998; Henriques et al., 1984); the complicity of psychology in maintaining current neoliberal regimes and inequitable social hierarchies has been dissected and highlighted (e.g. Parker and Shotter, 1992; Parker, 2007); and telling critiques of, and alternatives to, commonly used psychological notions such as intelligence, child development and memory have been produced (Bradley, 1989; Burman, 1994; Richardson, 2000; Middleton and Brown, 2005). Moreover, while those approaches characterized as discursive psychology (e.g. Edwards and Potter, 1992) suffer from notable shortcomings, their full implications for method - not just in psychology, but in any area of the social sciences where language is the medium whereby data are gathered - have yet to be widely appreciated. And similarly, within the UK at least, the effects of getting the qualitative methods associated with critical work onto the core curriculum of most undergraduate programmes will continue to ripple through the discipline for some years to come.

Critical psychology has received relatively little attention from other social sciences, despite its close links with them. When scholars from other disciplines have sought to supplement their critical perspectives with elements of psychology, they have frequently favoured non-controversial elements from its mainstream rather than work which, however excellent its scholarship, is rendered somewhat marginal by its critical import. But this has led to a paradox where colleagues from other disciplines are sometimes taking up psychological resources that their critical allies within psychology have already rejected. Just as biologists themselves have produced the most searching and detailed critiques of and alternatives to biological reductionism (Rose et al., 1984 [115]; S. Rose, 1997), so critical psychologists have generated versions of the psychological already informed by current trends elsewhere within the social sciences and so, potentially at least, highly suitable for integration with them. While critical psychology's challenge to the mainstream of the discipline has (unsurprisingly) failed to overturn its core commitment to individualism and reductionism, it has nevertheless generated a substantial body of high-quality scholarship, supported a generation of scholars who are working from the inside to subvert psychology's pernicious character, and fostered various high-profile initiatives (not least this very journal!) 


\section{So what happened to experience?}

\section{The situatedness of subjectivity: assemblages, actual occasions and experience}

Without casting any doubt upon the importance and centrality of the concept of subjectivity for contemporary critical inquiry in the social sciences and in the humanities, we also see - parallel to the debates that we presented earlier attempts to situate socio-historically the prevalent usages of this concept that lead to further reconsiderations and modifications of its content. The starting point of these attempts is related to the long critical history of social science and the humanities (Jaeger and Staeuble, 1978; Henriques et al., 1984; Canguilhem, 1988; Danziger, 1990; Bal, 2002) and the emerging tradition of critical social studies of science and technology (Winner, 1986; Haraway, 1994; Hess, 1995). This work, as we have seen in different ways, turns our attention to the cultural and socio-political locatedness and implications of concepts, theories and technologies. Subjectivity, despite its fruitfulness for critical research, possesses no trans-historical validity and cannot lie beyond historical specificity. Subjectivity as any other concept is seen as an active agent that shapes and is shaped by prevailing social, cultural and political spaces: The concept of subjectivity not only serves as a way to understand and tackle neo-liberal power relations and inequalities but it could in a paradoxical way be reinforcing them. This because neo-liberal power establishes a social order not primarily through liquidating otherness, inferiority or subjectivity, but by fabricating and regulating otherness and subalternity through the multiplication and assimilation of subjectivities that are created by one's own reflexivity of one's own positionality (Papadopoulos, 2003, 2008; Stenner, 2004; Ong, 2006). As Luhmann says: "Basic paradox of reflection: that it wants unity and generates difference" (Luhmann, 1985, p. 442).

Today's enigma of political action, the cultural logic of neo-liberalism, is such that the more people try to build a coherent, critical image for their social praxis, the more fragmented and incoherent it emerges; that is, the more people tend to fabricate cogent subversive knowledge of the world, the more they fabricate diversification that sustains the neo-liberal political apparatus. It is one of the main targets of this journal to foster debates that not only explore different approaches and conceptualizations of subjectivity but also investigate the current social and political usages and implications of this concept. Isabelle Stengers's article in this issue problematizes subjectivity from this perspective. What kind of practices do we create when we use the concept of subjectivity? Where do we locate ourselves when we use the concept of subjectivity as a critical tool for analysing the contemporary social and political situation? Isabelle Stengers argues that we can understand the efficacy of a concept as part of a milieu; that is to the extent that a concept creates an immanent line of flight 
and helps us to learn what affect us and what empowers us in our capacity to act. In this sense subjectivity could be never understood for itself, rather it is always part of an assemblage in which it is used and in which it gains its craft to forge efficacious propositions.

Deleuze and Guattari's work is important for understanding subjectivity in this historical conjuncture of the workings of neo-liberal governance and also the implicit possibilities for further development of the concept of subjectivity. As is well known, Deleuze and Guattari rarely use the concept of subjectivity and when they do it is mostly in a negative way: Subjectivity for Deleuze and Guattari is a molar event, a closure against the process of singular individuation and molecular becoming. Subjectivity constitutes a move to create a plane of consciousness that is essential for sustaining the mode of capture of the postsignifying regime, the regime that forms the milieu for the production of contained, fixed and molar subjects (Deleuze and Guattari, 1987, p. 129ff.). This problematization of subjectivity, which is obviously very different from the one presented earlier in the context of hegemony theory and governmentality, opens new vistas to conceive what could be its meaning in the beginning of the new century. In particular, the focus on singularities and assemblages offers possibilities to reconsider the content of the concept and its political ramifications. Following Deleuze and Guattari we could read subjectivity as decentred, as a part of an assemblage, an emergent conjunction and an evolving intertwining of self-ordering forces and diverse materialities. This understanding opens the path to rethink the subject-object relation outside of its modernist capture as opposite and binary categories, a topic that is extensively discussed in Isabelle Stengers' paper.

In addition, some argue that Whitehead can help us to move away from the primacy of consciousness (and therefore the sub- and unconscious) which has been so central for its Marxist and psychoanalytic understandings of subjectivity in the past 30 years. Instead of consciousness (and the unconscious) Whitehead is much more interested in experience: "Thus an actual entity may, or may not, be conscious of some part of its experience. Its experience is its complete formal constitution, including its consciousness, if any" (Whitehead, 1979, p. 53). Experience, as we already discussed in the beginning of this editorial, was always an important element for understanding subjectivity. This take on experience and subjectivity revitalizes the long political discussions on the role of experience which have always accompanied the concept of subjectivity. These discussions include not only the debates about various philosophical understandings of experience in the traditions of empiricism, vitalism (James, 1976; Bergson, 2001) or in cultural thought (Simmel, 1971; Benjamin, 1996; Jay, 2005) but also the ways in which everyday experience proved always crucial for instigating radical politics. Everyday experience was vital for feminist politics (Smith, 1987; Haug, 1992; H. Rose, 1994), standpoint epistemologies and anti-racist movements (Du Bois, 1903; Fanon, 1967; Hill 
Collins, 1991), for various formations of cultural politics (Williams, 1989; Rosaldo, 1993; Pickering, 1997) as well as for the urban movements after the 1960s (Debord, 1981; Lefebvre, 1991; Highmore, 2002). While the end of the 1980s and the 1990s and the rise of Foucauldian-inspired poststructuralism brought a mistrust of experience (Scott, 1991) and of standpoint epistemologies (Hekman, 1997) and forced subjectivity to retreat to the mere question of the production of the subject, Deleuze, Guattari, Whitehead, James and others remind us again that what it comes to is not so much how different subjectivities are fabricated through power (as governmentality theory tried to do), but how social reality is literally constructed and how subjectivity materializes in the social realm.

In this understanding subjectivity is always here and active; it is a force for making worlds that is indefinable and undecidable, a process that is incompatible with any notion of predetermination, transcendence, or timelessness (Simondon, 1992; Teilhard de Chardin, 1999). Subjectivity is always unfinished, partial, non-linear. It is unfinished because it exists only in the present (Schmitz, 2002), in the making of the real-time unfolding materiality of our body (MerleauPonty, 1968; Csordas, 1994); it is non-linear because it interrupts the linear determination and colonization of the present from the past (Vygotsky, 1934; Holzkamp, 1995; G. Rose, 1997); it is partial because we are not fully aware of how we become what we are: we are very often unable to retrieve back to its social genesis different aspects of the habitus of our bodies (Bourdieu, 1990).

These are, among many others, just a few possibilities to think of subjectivity as an undecidable and partial force and it is exactly these qualities of subjectivity that make it an active agent of social, political and cultural analysis and transformation. One of the many debates that this journal wishes to foster is how subjectivity can effectuate and promote social and political change today by nurturing interest in forces that escape the neo-liberal matrix of power not simply by negating or opposing it but by putting new alternative forms of sociability in motion. What it comes to is how subjectivities construct new materialities (Haraway, 1997; Schraube, 1998; Barad, 2007), how subjectivities force capitalist aggregates of power to reconstruct themselves (Moulier Boutang, 1998; Santos, 2001; Hardt and Negri, 2004), how subjectivities materialize in new cultural relations and relations of intimacy (Preciado, 2003; Mahmood, 2005; Clough and Halley, 2007), how, finally, subjectivities contribute to the emergence of new political engagements and new social movements (Rancière, 1998; Chesters and Welsh, 2006; Papadopoulos et al., 2008).

\section{Undoing subjectivity: the body and materiality}

In much of the work we have discussed above, the concept of subjectivity is replaced with a focus upon bodies, where bodies are not singular, bounded, closed and fixed, but rather open to being affected and affecting others. Within this formulation attention is shifted to what bodies can $d o$, and what relational connections change and alter bodies as they move and sense in the world. Some 
of this work also moves beyond the isolated human body in its focus and looks at the coupling of the human body with technology, nature, machines, animals and spirits, for example. Bodies are never simply stabilized effects of the subjectpositions that precede them. These critiques of "cultural inscription" and social constructionist approaches to the production of subjectivity have drawn attention to the lack of bodily agency often implied within such perspectives. That is, that there is not a tight fit or homology between subject positions and subjectivity (this takes us back someway to the work in Changing the Subject, which moved to psychoanalytic accounts to theorize how the subject could "hold together" without seeing subjectivity as simply the sum total of discourses from birth). Indeed, the body has been a major source of interest in the social sciences for at least the last two decades so that now, jostling for place alongside the natural or biological body, we have gendered, transgendered, racialized, classed and sexualized bodies (e.g. Butler, 1993a, b; Neal, 1998; Prosser, 1998; Skeggs, 2004). Intersecting these we have bodies that are alternatively, and sometimes simultaneously, phenomenological, relational and discursive, bodies that are metaphorical, cyborged, performative, disciplined, ordered, disordered, positioned, or constructed (e.g. Dery, 1995; Wilson, 1996; Burkitt, 1999; Crossley, 2001; Shilling, 2003).

Generalizations referring to any such heterogeneous assortment of work quickly encounter exceptions; nevertheless, certain themes and issues recur. Most obviously, as feminists have long observed, the interdependent scourges of essentialism, reductionism and dualism are ever present, as scholars strive to incorporate the body without either ceding it to biology or splitting it from culture. In turn, studied efforts to sidestep these problems give rise to the lament, seemingly voiced from every side, that the actual fleshy body of skin, muscle, tendons, synapses and blood has been eviscerated, becoming not so much a body-without-organs as a body without any material substance whatsoever (e.g. Crossley, 1995; Hughes and Paterson, 1997; Stam, 1998; Nightingale, 1999; Braun, 2000). Attempts to remedy these problems sometimes involve the coining of neologisms (e.g. "somatechnics"), whose promise to transcend dualism and negate essentialism seems to come only at the cost of subordinating the body to further conceptualization and so, implicitly at least, further dematerializing the lived flesh: as Robertson (2001) puts it, embodiment all too frequently means "enmindment". At the same time, however, attempts to incorporate the body by straightforwardly integrating social science with the natural sciences of the body continue to founder on apparently irreconcilable differences (see Newton, 2007). Clearly, these problems will not be resolved in the short term.

Despite these difficulties there is an undeniable sense of vigour and relevance in much of this work. Bodies are the locus of contemporary political formations in regimes of biopower and biopolitics (Rose and Rabinow, 2006), they are the target and raison d'être of new technologies in genomics, neuroscience and medicine, and the object of governance and policy with respect to health 
(smoking, obesity, healthcare rationing, self-monitoring), reproduction (access to fertility treatment, the resurgent debate on abortion) age, mortality and longevity. The body is a boundary object that articulates elements of various social science disciplines and raises similar questions within each. Sometimes celebrated as inherently transgressive, since it is both the object and locus of desire, the body must in any case contribute to any coherent understanding of subjectivity because, as Merleau-Ponty (2002) observed, it is the means by which there is any world for us at all. Subjectivity is always embodied subjectivity, although there continues to be vigorous and healthy disagreement concerning the ways in which this embodiment should be most fruitfully conceptualized.

A prominent recent trend in this work is the extensive engagement, particularly within the pages of the journal Body and Society, with the relations between the body and several of our world's cultures. There is also a clear sense in which the putative and emergent "affective turn" might be seen as a continuation of interest in the body by other means. Perhaps most striking, however, has been the recent uptake of elements of contemporary neuroscience; Damasio's work, in particular, has been utilized within fields as diverse as social theory, cultural studies, critical psychology, economics and politics, personality theory, psychopathology, ethics and art (Cromby, 2007). Damasio's widespread appeal seems to reside in his apparent ability to slide between synapse and society in a way that makes coherent links between both, while at the same time carrying the imprimatur of respectable science. His "somatic marker" hypothesis (Damasio, 1994) describes a neural mechanism whereby social norms might get quite literally embodied and feed forward into decisionmaking, thus challenging the disembodied cognitivism of many accounts and placing the lived phenomenological body at the centre of social life. Nevertheless, there are some conceptual flaws in this work (Bennett and Hacker, 2003), and its political utility seems to run largely counter to Damasio's own proclivities and certainly contradicts his own reactionary attempts at social theorizing (Damasio, 2003). Moreover, the limits of his engagement with the body are illustrated by contrast both with other work in affective neuroscience (Panksepp, 2004) and with Wilson's (2004) account that thoroughly decentres cognition from the brain to an axis that also includes the gut. In future, further potentials may arise from neuroscience with respect to accumulating empirical evidence (much of it from MRI studies), suggesting that socialization and the effects of experience drill down to the very level of synapse and brain structure: that the brain itself is in fact socialized.

Our hope is that Subjectivity will become a forum where these and other debates continue to get played out. While we envisage it being open to any of the existing variety of social science perspectives upon the body, our emphasis on politics and subjectivity suggests that certain concerns are likely to be of particular future relevance. For example, we imagine that the journal could be a place where re-ontologizations of the body might continue to be rehearsed, such 
that the materialist potentials of scholars such as Deleuze, Guattari and Whitehead, for example, might inform, and be informed by, situated analyses of the lived, enculturated body. The need to avoid essentialism and reductionism, and to evoke the intimacies of the lived body without falling prey to dualism, mean that body theorizing is sometimes couched in hallucinatory or Jesuitical language. Such writing insulates theory from recuperation and, superficially at least, avoids re-inscribing dualism, but at the same time can give it an overly reflexive, indulgent and sometimes auto-suppositorial character. By contrast, we want this journal to clearly demonstrate the relevance of new theory by demonstrating theory's relevance to contemporary social and political concerns.

These problems in body theorizing are, we feel, reflective of a more widespread contemporary tendency within the social sciences to simply avoid, by largely rhetorical means, the phenomena of fixedness and continuity. Entirely understandable in these reactionary times, this tendency nevertheless has negative political consequences since it disengages scholarship from some of the concrete particulars of lived experience. Reflecting in part the class location and material conditions of most who produce it, perhaps, theory's current emphases on fluidity and multiplicity frequently fail to consider how they actually co-exist, for many, with grinding stability and exploitative continuity. This tension is starkly foregrounded by work on the body, since the body is not only a vehicle for becoming. If we take seriously what scholars such as Bourdieu and Iris Marion Young have to say, the body is also the place where social influence gets stuck, where process becomes a standing wave, its activities trained and regimented in ways that do much to facilitate the reproduction of (for example) class and gender inequality. While there are no easy answers here, this problem might perhaps be countered by a particularity of engagement that addresses materiality within coherent and detailed accounts of the totality of the specific relations obtaining between body, subjectivity and world. Similarly, we imagine that contributions to the journal might particularly explore the relationship between body and subjectivity, in an attempt to better understand just how this relationship can sustain such a variety of conceptualizations of the body. These contributions could usefully interrogate the sensitive interdependence of subjectivity, body and world, given that the profusion of viable social science conceptualizations of the body that we have sketched nevertheless co-exist with its relative spatio-temporal boundedness and inescapable mortal finitude.

Similar debates can be found in feminism with splits and divisions between those who find psychoanalytic theorizations of subjectivity useful and those who posit internalization as an account of how gendered differences come to matter (Bordo, 1993). Although this is a rather crude distinction, one of the key problems for theorizing subjectivity within feminist sociology, for example, has been the lack of non-dichotomous concepts and vocabularies for understanding processes of subject formation. The usefulness of Deleuzian concepts for many feminists has been posed in relation to the limitations of what are described as 
social constructionist or cultural inscription models of subject formation that have been central to the sociological imagination (Howson, 2005). Both Elizabeth Grosz and Rosi Braidotti bring together insights from Deleuzian approaches to subjectivity with theorizations of the unconscious to "think" of subjectivity as a non-dualistic process. The focus of this work is the importance of maintaining a notion of the psychic or psychical to address the injunction in advanced liberal democracies that we experience ourselves as coherent, whole and unified. Braidotti, like Grosz, argues that what is important are affect, desire and imagination and how these are organized, channelled and transformed. The question for Braidotti (2002) is how we string together a sense of self, "under the fictional unity of an I" (p. 22) in the face of "power, struggles and contradictions" (p. 25). This work reminds us how transformations or resistance to cultural norms are not simply due to acts of will or volition. Braidotti (2002, p. 40) argues that although cultural norms act like magnets, "drawing the self in certain directions", we do not simply internalize them in any straightforward fashion. This opens up investigations of subjectivity to a complex realm of affectivity that is little known or understood, but is felt in a very real and profound way. It is this move to a realm of affectivity that is distinctive of work across the humanities which is attempting to re-introduce movement into what is taken to be the fixity of constructionist perspectives (Massumi, 2002). However, when read alongside work that has developed within critical psychology over the last 30 years, the aims of these differing positions are not as far apart as we might have first thought.

The transdisciplinary interest in subjectivities signals an exciting time to launch a new journal devoted to discussions of subjectivity. We see the limits and problems of "discourse" and cultural inscription models forming the target and object of a range of work across the humanities. Some are heralding a paradigm shift, as seismic as the earlier shift from ideology to discourse that is transforming the landscape and conceptual terrain of subjectivity (Clough and Halley, 2007). This "turn to affect" signals a moment when the boundaries and splits between the natural and human sciences no longer seem tenable. Where in work on discourse, if bodily matters were considered these were as effects of discursive practices, the natural sciences are now becoming authorized sites for humanities scholars to poach and invent new vocabularies for re-thinking subjectivity. The psychological sciences have also become favoured knowledge practices to borrow from, with developmental, cognitive and neuroscience providing a range of concepts for addressing what are taken to be the relational aspects of subjectivity. What this work fails to take account of is the long engagement of psychologists with problems within the discipline. We do not feel that the invention of potential new ontologies can go wholesale to psychology as a way of backing up radical claims within the humanities, when the psychological sciences tend to work with a static and originary subject with a 
fixed developmental ontology (Brennan, 2004). Cautious reflection and engagement are obviously needed.

\section{Contributors}

We are very excited about the contribution of leading scholars across the humanities and social sciences to our first two launch issues of Subjectivity. The invited contributors were asked to explore the concept of subjectivity in relation to their own research, writing and disciplinary field. We are delighted to open up plurality and diversity by having contributions from the disciplines of science and technology studies, philosophy, psychoanalysis, critical psychology, geography, psychosocial studies and anthropology. This is echoed in the second issue, which will also see some exciting contributions from leading scholars across these fields including Betty Bayer, Ian Burkitt, Patricia Clough, Vicianne Despret, Lilli Hsieh, Andrew Metcalfe and Ann Game, Desmond Painter, and Steve Pile. What is also very striking by bringing scholars from different disciplines together are the differing ways in which concepts such as affect, relationality and subjectivity are mobilized and how any self-evidence of such concepts must be placed under question. In this issue, Annemarie Mol, the Dutch science studies scholar, has offered an amusing and provocative piece of performative writing that foregrounds relationality and connectedness through practices of eating, as a way of moving subjectivity away from any notion of fixity or singularity. This is also echoed by the American anthropologist, Thomas Csordas, who moves discussions of affective and gestural forms of communication, such as the laying on of hands, the chanter's lips and the grimace-smile into a realm of intercorporeality that is thoroughly relational and reciprocal. Bodies are never singular but open, porous and permeable, thus changing, Csordas suggests, how we might approach the realm of non-verbal communication. We are also delighted to have the philosopher Isabelle Stengers and her contribution which we have discussed in relation to the importance of Whitehead's revitalization across the humanities in the section on the importance of experience. Paul Stenner, a psychosocial studies scholar, also interrogates the work of Whitehead, while eminent geographer, Nigel Thrift engages with what it means to make a decision, as a way of making visible some of the dilemmas of where to locate subjectivity. This takes the geography of subjectivity away from place and singularity to the importance of duration and movement, captured by his call for an epidemiology of subjectivity and the importance of the concepts of invention and experimentation. Margie Wetherell, a social psychologist, examines subjectivity from the standpoint of discursive identity research, being wary of a concept of subjectivity that seems to disclose the private and personal and that does not engage with the discursive practices through which identities are constructed. Lynne Layton, a relational psychoanalyst, argues that in attempting to understand subjectivity, 
psychoanalysts should not easily separate the psychic from the social. To that end, she argues, we need to understand that the very way our psychic structures become intertwined with split gender, race, sexual, class and other identity investments not only divides subjects against each other but also divides the subject against itself. These two accounts, when taken together, show us something interesting about the ways that those academics from different branches of the psy sciences struggle to understand the complex production of subjectivities in the present. It is to the complexities of these struggles that this first issue now turns and we welcome responses, in the form of papers, to the issues we have opened up for discussion and that are cogently illustrated by our contributors.

\section{References}

Adlam, D., Henriques, J., Rose, N., Salfield, A., Venn, C. and Walkerdine, V. (1976). Psychology, Ideology and the Human Subject. Ideology and Consciousness, 1, pp. 1-26.

Althusser, L. (1971). Ideology and Ideological State Apparatuses. In Brewster, B. (ed.) Lenin and Philosophy. London: New Left Books, pp. 127-186.

Badiou, A. (1988). L'Etre et l'événement. Paris: Editions du Seuil.

Bal, M. (2002). Travelling Concepts in the Humanities: A Rough Guide. Toronto: University of Toronto Press.

Barad, K.M. (2007). Meeting the Universe Halfway. Quantum Physics and the Entanglement of Matter and Meaning. Durham: Duke University Press.

Bayer, B.M. and Shotter, J. (eds) (1998). Reconstructing the Psychological Subject: Bodies, Practices and Technologies. London: Sage Publications.

Benjamin, W. (1996). Selected Writings Vol. 1: 1913-1926. Cambridge, MA: Harvard University Press.

Bennett, M.R. and Hacker, P.M.S. (2003). Philosophical Foundations of Neuroscience. Oxford: Blackwells.

Bergson, H. (2001). Time and Free Will: An Essay on the Immediate Data of Consciousness. Mineola, NY: Dover Publications.

Bhabha, H.K. (2004). The Location of Culture. London and New York: Routledge.

Blackman, L. (2001). Hearing Voices: Embodiment and Experience. London and New York: Free Association Press.

Blackman, L. (2007). Reinventing Psychological Matters. The Importance of the Suggestive Realm of Tarde's Ontology'. Economy and Society, 36(4), pp. 574-596.

Blackman, L. (2008). Affect, Relationality and the Problem of Personality. Theory, Culture and Society, 25(1), pp. 27-51.

Bourdieu, P. (1990). The Logic of Practice. Cambridge, UK: Polity Press.

Bordo, S. (1993). Unbearable Weight: Feminism, Western Culture and the Body. Berkeley: University of California Press.

Bradley, B. (1989). Visions of Infancy. Oxford: Polity Press/Blackwells.

Braidotti, R. (2002). Metamorphoses: Towards a Materialist Theory of Becoming. Oxford: Polity Press.

Braun, V. (2000). Conceptualising the Body. Feminism and Psychology, 10, pp. 511-518. 
Braverman, H. (1974). Labour and Monopoly Capital. New York: Monthly Review Press. Brennan, T. (2004). The Transmission of Affect. Ithaca, NY: Cornell University Press.

Burkitt, I. (1999). Bodies of Thought: Embodiment, Identity and Modernity. London: Sage Publications.

Burman, E. (1994). Deconstructing Developmental Psychology. London: Routledge.

Butler, J. (1993a). Bodies That Matter: On the Discursive Limits of Sex. New York: Routledge.

Butler, J. (1993b). Endangered/Endangering: Schematic Racism and White Paranoia. In Gooding-Williams, R. (ed.) Reading Rodney King/Reading Urban Uprising. New York: Routledge, pp. 15-22.

Canguilhem, G. (1988). Ideology and Rationality in the History of the Life Sciences. Cambridge, MA: MIT Press.

Chesters, G. and Welsh, I. (2006). Complexity and Social Movements: Multitudes at the Edge of Chaos. London: Routledge.

Clough, P.T. (2000). Autoaffection: Unconscious Thought in the Age of Teletechnology. Minneapolis: University of Minnesota Press.

Clough, P.T. and Halley, J.O.M. (2007). The Affective Turn. Theorizing the Social. Durham, NC: Duke University Press.

Connolly, W.E. (2002). Neuropolitics: Thinking, Culture, Speed. Minneapolis: University of Minesota Press.

Cromby, J. (2007). Integrating Social Science with Neuroscience: Potentials and Problems. Biosocieties, 2, pp. 149-169.

Crossley, N. (1995). Merleau-Ponty, The Elusive Body and Carnal Sociology. Body and Society, 1, pp. 43-63.

Crossley, N. (2001). The Social Body: Habit, Identity and Desire. London: Sage Publications.

Csordas, T.J. (ed.) (1994). Embodiment and Experience: The Existential Ground of Culture and Self. Cambridge, New York: Cambridge University Press.

Damasio, A.R. (1994). Descartes Error: Emotion, Reason and the Human Brain. London: Picador.

Damasio, A.R. (2003). Looking for Spinoza: Joy, Sorrow and the Feeling Brain. Orlando: Harvest.

Danziger, K. (1990). Constructing the Subject: Historical Origins of Psychological Research. Cambridge: Cambridge University Press.

Debord, G. (1981). Perspectives for Conscious Alterations in Everyday Life. In Knabb, K. (ed.) Situationist International Anthology. Berkeley, CA: Bureau of Public Secrets, pp. 68-75.

De Lauretis, T. (1984). Alice Doesn't: Feminism, Semiotics, Cinema. Bloomington: Indiana University Press.

Deleuze, G. (1990). Negotiations. 1972-1990. New York: Columbia University Press.

Deleuze, G. and Guattari, F. (1987). A Thousand Plateaus: Capitalism and Schizophrenia. Minneapolis: University of Minnesota Press.

Dery, M. (1995). Escape Velocity: Cyberculture at the End of the Century. London: Hodder and Stoughton.

Du Bois, W.E.B. (1903). The Souls of Black Folk: Essays and Sketches. Chicago: A.C. McClurg and Co. 
Edwards, D. and Potter, J. (1992). Discursive Psychology. London: Sage Publications.

Fanon, F. (1967). Black Skin, White Masks. New York: Grove Press.

Feltham, O. and Clemens, J. (2003). An Introduction to Alain Badiou's Philosophy. In Feltham, O. and Clemens, J. (eds) Infinite Thought Truth and the Return to Philosophy. London and New York: Continuum, pp. 1-28.

Foucault, M. (2006). Psychiatric Power: Lectures at the Collège de France 1973-1974. Lagrange, J. (ed.) London and New York: Palgrave.

Gilroy, P. (2004). After Empire: Melancholia or Convivial Culture? London and New York: Routledge.

Gramsci, A. (1971). Selections from the Prison Notebooks of Antonio Gramsci. Hoare, Q. and Nowell-Smith, G. (eds) New York: International Publishers.

Hall, S. and Jefferson, T. (1989). Resistance through Rituals: Youth Subcultures in Postwar Britain. London and New York: Routledge.

Haraway, D.J. (1994). A Game of Cat's Cradle. Science Studies, Feminist Theory, Cultural Studies. Configurations, 1, pp. 59-72.

Haraway, D.J. (1997). Modest_Witness@Second_Millennium. FemaleMan(c_Meets_ OncoMouse ${ }^{\mathrm{TM}}$ : Feminism and Technoscience. New York: Routledge.

Hardt, M. and Negri, A. (2004). Multitude: War and Democracy in the Age of Empire. New York: The Penguin Press.

Haug, F. (1992). Beyond Female Masochism: Memory-work and Politics. London/ New York: Verso.

Hebdige, D (1979). Subculture: The Meaning of Style. London: Methuen.

Hekman, S. (1997). Truth and Method: Feminist Standpoint Theory Revisited. Signs, 22(2), pp. 341-365.

Hemmings, C. (2005). Invoking Affect: Cultural Theory and the Ontological Turn. Cultural Studies, 19(5), pp. 548-567.

Henriques, J., Hollway, W., Urwin, C., Venn, C. and Walkerdine, V. (1984). Changing the Subject: Psychology, Social Regulation and Subjectivity. London: Methuen.

Hess, D.J. (1995). Science and Technology in a Multicultural World: The Cultural Politics of Facts and Artifacts. New York: Columbia University Press.

Highmore, B. (2002). Everyday Life and Cultural Theory: An Introduction. London: New York: Routledge.

Hill Collins, P. (1991). Black Feminist Thought: Knowledge, Consciousness, and the Politics of Empowerment. New York: Routledge.

Hoggart, R. (1971). The Uses of Literacy. London: Chatto and Windus.

Holzkamp, K. (1995). Kolonisierung der Kindheit. Psychologische und psychoanalytische Entwicklungserklärungen. Forum Kritische Psychologie, 35, pp. 109-131.

Hook, D. (2005). A Critical Psychology of the Postcolonial. Theory and Psychology, 15(4), pp. 475-503.

Hook, D. (2007). Foucault, Psychology and the Analytics of Power. London and New York: Palgrave-Macmillan.

Howson, A. (2005). Embodying Gender. London: Sage.

Hughes, B. and Paterson, K. (1997). The Social Model of Disability and the Disappearing Body: Towards a Sociology of Impairment. Disability and Society, 12(3), pp. 325-340.

Ibanez, T. and Iniguez, L. (eds) (1997). Critical Social Psychology. London: Sage Publications. 
Jaeger, S. and Staeuble, I. (1978). Die gesellschaftliche Genese der Psychologie. Frankfurt am Main: Campus.

James, W. (1976). Essays in Radical Empiricism. Cambridge: Harvard University Press.

Jay, M. (2005). Songs of Experience: Modern American and European Variations on a Universal Theme. Berkeley: University of California Press.

Lacan, J. (1977). The Four Fundamental Concepts of Psychoanalysis. London: Hogarth Press/Penguin.

Lacan, J. (2002). Ecrits - A Selection. New York: W. W. Norton \& Co., Inc.

Lefebvre, H. (1991). Critique of Everyday Life. Vol.1: Introduction: Verso. London and New York: Verso.

Luhmann, N. (1985). Die Autopoiesis des Bewusstseins. Soziale Welt, 36, pp. 402-446.

Mahmood, S. (2005). Politics of Piety: The Islamic Revival and the Feminist Subject. Princeton, NJ, Oxford: Princeton University Press.

Massumi, B. (2002). Parables for the Virtual. Movements, Affect, Sensation. Durham and London: Duke University Press.

McRobbie, A. (2005). The Uses of Cultural Studies. London: Sage.

Merleau-Ponty, M. (1968). The Visible and the Invisible. Lingis, A. (trans.). Evanston, IL: Northwestern University Press.

Merleau-Ponty, M. (2002). Phenomenology of Perception. London: Routledge.

Middleton, D. and Brown, S. (2005). The Social Psychology of Experience: Studies in Remembering and Forgetting. London: Sage.

Mitchell, J. (1974). Psychoanalysis and Feminism. London, Penguin.

Mitchell, J. and Rose, J. (eds) (1983). Feminine Sexuality: Jacques Lacan and the Ecole Freudienne. Basingstoke and New York: Macmillan Press.

Moore-Gilbert, B. (1997). Postcolonial Theory Contexts, Practices, Politics. London: Verso.

Moulier Boutang, Y. (1998). De l'esclavage au salariat. Economie historique du salariat bridé. Paris: Presses Universitaires de France.

Murray, M. (2004). Critical Health Psychology. London: Palgrave.

Neal, S. (1998). Embodying Black Madness, Embodying White Femininity: Populist (Re)Presentations and Public Policy - The Case of Christopher Clunis and Jayne Zito [WWW document]. Sociological Research Online, 3, http://www.socresonline.org.uk/3/ 4/2.html (accessed 15 November 2007).

Newton, T. (2007). Nature and Sociology. London: Routledge.

Nightingale, D.J. (1999). Bodies: Reading the Body. In Parker I. and The Bolton Discourse Network (eds) Critical Textworks. Buckingham: Open University Press, pp. 167-177.

Ong, A. (2006). Neoliberalism as Exception. Mutations in Citizenship and Sovereignty. Durham, NC: Duke University Press.

Orbach, S. (1978). Fat is a Feminist Issue. London: Hamlyn.

Orr, J. (2006). Panic Diaries: A Genealogy of Panic Disorder. New York: Duke University Press.

Panksepp, J. (2004). Emotional Consciousness: Animalian Sources of Affective Values and the Core Self. Paper presented at the Science, Self and Meaning conference (annual conference of the Consciousness and Experiential Psychology Section of the British Psychological Society), Oxford.

Papadopoulos, D. (2003). The Ordinary Superstition of Subjectivity. Liberalism and Technostructural Violence. Theory and Psychology, 13(1), pp. 73-93. 
Papadopoulos, D. (2008). In the Ruins of Representation: Identity, Individuality, Subjectification. British Journal of Social Psychology, 47(1), pp. 139-165.

Papadopoulos, D., Stephenson, N. and Tsianos, V. (2008). Escape Routes Control and Subversion in the 21st Century. London: Pluto Press.

Parker, I. (2007). Revolution in Psychology. London: Pluto Press.

Parker, I. and Shotter, J. (eds) (1992). Deconstructing Social Psychology. London: Routledge.

Pickering, M. (1997). History, Experience, and Cultural Studies. New York: St Martin's Press.

Preciado, B. (2003). Kontrasexuelles Manifest. Berlin: bbooks.

Prosser, J. (1998). Second Skins: The Body Narratives of Transsexuality. New York: Columbia University Press.

Rancière, J. (1998). Disagreement: Politics and Philosophy. Minneapolis: University of Minnesota Press.

Richardson, K. (2000). The Making of Intelligence. New York/Chichester: Columbia University Press.

Robertson, A.F. (2001). Greed: Gut Feelings, Growth and History. Cambridge: Polity Press.

Rosaldo, R. (1993). Culture and Truth: The Remaking of Social Analysis. Boston: Beacon Press.

Rose, G. (1997). Love's Work. London: Vintage.

Rose, H. (1994). Love, Power and Knowledge. Cambridge: Polity Press.

Rose, N. (1985). The Psychological Complex. London: Routledge.

Rose, N. (1998). Inventing Ourselves: Psychology, Power and Personhood. Cambridge: Cambridge University Press.

Rose, N. and Rabinow, P. (2006). Biopower Today. Biosocieties, 1, pp. 195-217.

Rose, S. (1997). Lifelines: Life Beyond the Gene. Oxford: Oxford University Press.

Rose, S., Lewontin, R. and Kamin, I. (1984). Not in Our Genes. Harmondsworth: Penguin.

Santos, B.d.S. (2001). Nuestra America: Reinventing a Subaltern Paradigm of Recognition and Redistribution. Theory, Culture and Society, 18(2/3), pp. 185-218.

Schmitz, H. (2002). Die Gegenwart. In Gutmann, M., Hartmann, D., Weingarten, M. and Zitterbarth, W. (eds) Kultur - Handlung - Wissenschaft: für Peter Janich. Weilerswist: Velbrück Wissenschaft, pp. 27-42.

Schraube, E. (1998). Auf den Spuren der Dinge: Psychologie in einer Welt der Technik. Berlin: Argument-Verlag.

Scott, J.W. (1991). The Evidence of Experience. Critical Inquiry, 17(4), pp. 773-797.

Shilling, C. (2003). The Body and Social Theory, 2nd ed. London: Sage Publications.

Simmel, G. (1971). On Individuality and Social Forms. Selected Writings. Chicago: University of Chicago Press.

Simondon, G. (1992). The Genesis of the Individual. In Crary, J. and Kwinter, S. (eds) Incorporations. New York, NY: Zone, pp. 297-319.

Skeggs, B. (2004). Class, Self and Culture. London and New York: Routledge.

Smail, D.J. (2005). Power, Interest and Psychology: Elements of a Social Materialist Understanding of Distress. Ross-On-Wye: PCCS Books. 
Smith, D.E. (1987). The Everyday World as Problematic: A Feminist Sociology. Boston: Northeastern University Press.

Stafford, B. (2007). Echo Objects: The Cognitive Work of Images. Chicago: University of Chicago Press.

Stam, H. (ed.) (1998). The Body and Psychology. London: Sage Publications.

Stenner, P. (2004). Psychology and the Political: On the Psychology of Natural Right and the Political Origins of Modern Psychology. International Journal for Critical Psychology, 12, pp. 14-37.

Stephenson, N. and Papadopoulos, D. (2006). Analysing everyday experience. Social research and political change. London: Palgrave Macmillan.

Teilhard de Chardin, P. (1999). The Human Phenomenon. Brighton: Sussex Academic Press.

Thompson, E.P. (1963). The Making of the English Working Class. London: Victor Gollancz.

Thompson, E.P. (1980). Writing by Candlelight. London: Merlin Press.

Vygotsky, L.S. (1934). Thinking and speech. In Rieber, R.W. and Carton, A.C. (eds) The Collected Works of L.S. Vygotsky. Bd. 1: Problems of General Psychology. New York: Plenum, pp. 39-285.

Walkerdine, V. (1990). Schoolgirl Fictions. London: Verso.

Walkerdine, V. (2007). Children, Gender, Video Games. Basingstoke and New York: Palgrave.

Whitehead, A.N. (1979). Process and Reality: An Essay in Cosmology (Corrected/edited by David Ray Griffin and Donald W. Sherburne). New York: Free Press.

Williams, R. (1977). Marxism and Literature. Oxford: Oxford University Press.

Williams, R. (1989). Culture is Ordinary. In Williams, R. and Gable, R. (eds) Resources of Hope: Culture, Democracy, Socialism. London: Verso, pp. 3-18.

Wilson, E.A. (1996). Loving the Computer: Cognition, Embodiment and the Influencing Machine. Theory and Psychology, 6(4), pp. 77-599.

Wilson, E.A. (2004). Psychosomatic: Feminism and the Neurological Body. Durham/ London: Duke University Press.

Winner, L. (1986). The Whale and the Reactor: A Search for Limits in an Age of High Technology. Chicago: University of Chicago Press.

Young, R. (1990). White Mythologies: Writing History and the West. London and New York: Routledge. 